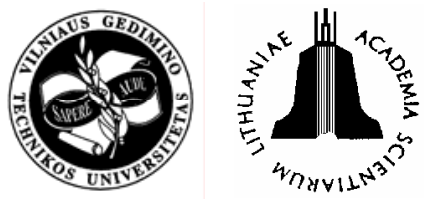

\title{
STRENGTH OF MINING AND BUILDING EQUIPMENT MATERIALS SUBJECTED TO GIGACYCLE LOADING
}

\author{
Mindaugas Kazimieras Leonavičius ${ }^{1}$, Gediminas Petraitis ${ }^{1}$, Marijonas Šukšta ${ }^{1}$, Vytas Svalbonas ${ }^{2}$ \\ ${ }^{1}$ Dept Strength of Materials, Vilnius Gediminas Technical University, Sauletekio al. 11, \\ LT-10223 Vilnius, Lithuania. \\ ${ }^{2}$ Metso Minerals Industries, Inc. Arch Street, P.O. Box 15312, York, PA 17405-7312, USA. \\ E-mail: ${ }^{1}$ marsu@fm.vtu.lt, ${ }^{2}$ vytas.svalbonas@metso.com \\ Received 09 Jan 2006; accepted 16 March 2006
}

\begin{abstract}
High-strength cast iron is used for manufacturing the supporting elements of minerals and cement clinker grinding machines. The dross layer remains inside large dimension castings after manufacturing. It has worse mechanical properties and resistance to fatigue crack formation and propagation. In this paper, the results of an experimental investigation of cyclic bending strength of semi-natural specimens from cast iron with a dross layer of $10-11 \mathrm{~mm}$ thickness are presented. The mechanical properties and structures of the base and dross layers differed considerably. Before testing the methods of defectoscopy were applied to detect technology defects. The stress ratio was $r=-0,62$ and the stress alternating range varied from 70 to $280 \mathrm{MPa}$. To $1 \cdot 10^{8}$ cycles, crack growth was insignificant. Further crack propagation was controlled. The $1^{\text {st }}$ specimen was broken after $3 \cdot 10^{8}$ and the $2^{\text {nd }}$ one after $2 \cdot 10^{8}$ cycles. The dependencies of crack propagation on cycle number and stress intensity factor range were estimated. The dross layer stops crack propagation, when crack front passes from dross to base metal.
\end{abstract}

Keywords: clinker mills, fatigue, crack propagation, stress intensity threshold.

\section{Introduction}

The problems of strength and reliability of newly built and old buildings are closely connected with mechanical properties of the materials used and the ability of cracked structural elements to resist the environmental effects. The use of new materials, methods of calculation and criteria at the stage of design can ensure safe service of newly designed buildings. In the elements or structures which have been in service for some time, permanent deformations may occur or the mechanical properties of materials may change due to variable loads. Therefore, to increase the guaranteed life of such structural units, they should be renewed (sometimes, even replaced), by the systems of elements ensuring their further safe service. Any strength theory or method of calculation should be based on modern research and experiments as well as on analytic studies and numerical analysis aimed at evaluating the mechanical state of any structural element. The failures of actual bodies depend on their structure, chemical composition, type of loading, defects, environmental effects and other factors. Therefore, in order to determine the strength of a solid body or to predict and control its failure, the parameters of micro and macro failure processes should be considered [1-6].

The problems of fatigue strength associated with the failure of metal units under variable cyclic load which is far below the fatigue limit have been known for a long time now, however, their analysis is still needed. In recent years, a great emphasis has been placed on investigating gigacycle fatigue when the number of cycles is above $10^{9}$. The well-known investigations in this area were performed by Bathias [6]. The extension of the fatigue limit is associated with the fact that at present the service life of the most critical structures reaches $50-100$ years. The investigations have shown that under $10^{8}-10^{9}$ loading cycles, the fatigue limit in the above range decreases; therefore, the conception of unlimited durability in the range of stresses below the limit is not true. Therefore, the methods used so far to determine the service life of structural elements can hardly yield reliable results. It is mainly accounted for by the changes of the causes and mechanisms of fatigue crack formation and failure of structures, which, despite intense research, still remain unexplained for fatigue caused by gigacycle loading [7-9]. The research of this phenomenon is complicated because it is difficult to determine the extent of failure and defects under a small range of loads by non-destructive testing. Methods of controlling fatigue crack formation under a large number of loading cycles based on well-known physical phenomena are needed.

\section{Loading analysis}

According to Makhutov [9], fatigue has some specific features, depending on the number of cycles and failure mechanisms. They are as follows:

$10^{0}-10^{1}$ decacycle failure influenced by emergency factors; 
$10^{0}-10^{3}$ hectocycle fatigue characterised by large microplastic deformations in a failure zone at macrostructural level;

$10^{3}-10^{5}$ kilocycle fatigue observed in the presence of relatively small macroplastic deformations in a failure zone at macr'oscopic level;

$10^{5}-10^{8}$ megacycle fatigue developing in the presence of microplastic deformations at micro- and macroscopic level near a failure zone;

$10^{8}-10^{9}$ gigacycle fatigue failure occurring under a great number of loading cycles and microplastic deformations at microscopic level near a failure zone;

$10^{10}-10^{12}$ teracycle fatigue observed under a very great number of loading cycles, with the deformations occurring at macrostructural level.

The performance of complex structures and equipment is associated with variable external loads of particular elements, with the number of cycles ranging from $10^{\circ}$ to $10^{9}$. To ensure durability (longevity) of these structures, their installation, use, emergency operation, control and technological modes should be considered and based on theoretical research and practical testing.

To ensure the strength and reliability of large buildings, power plants, vehicles and mining equipment, methods of calculation based on the theories of elasticity, plasticity, adaptability and failure are used. These methods rely on the analysis of the conditions of structural element loading and deformation as well as on theoretical research and testing.

For many structures, including mining machinery, the service problems are similar. In Fig 1 the variation of loading parameters of various structures under operational conditions is shown [9].

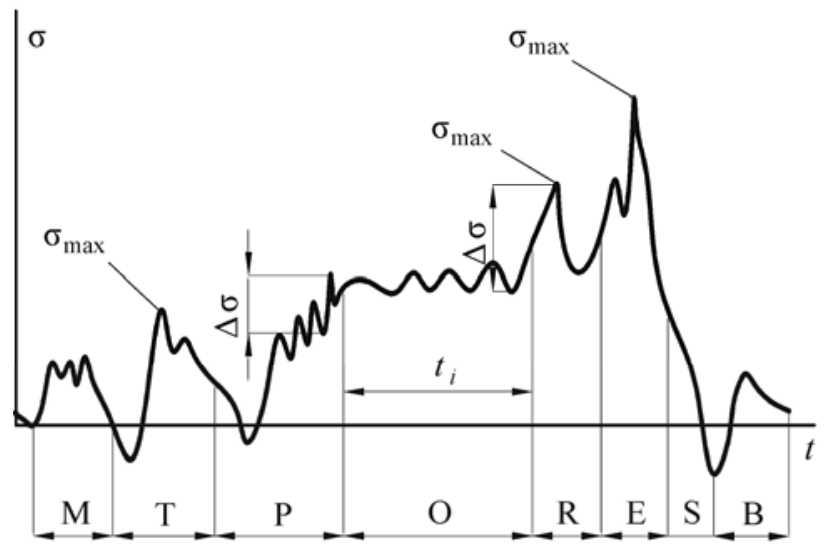

Fig 1. A workload scheme: $\mathrm{M}$ - installation (mounting), $\mathrm{T}-$ testing, $\mathrm{P}-$ putting into operation, $\mathrm{O}-$ stationary operation mode, $\mathrm{R}$ - regulation, $\mathrm{E}$ - emergency, $\mathrm{S}$ - shutting down, B - braking

Loading parameters include mechanical, electromagnetic, inertial and gravitational loads, pressure, and temperature. These factors generate stresses $\sigma\left(\sigma_{\max }, \sigma_{\min }\right.$, $\left.\sigma_{a}, \Delta \sigma\right)$ and deformations. The operational time $t$ of a structure may be divided into the stages of installation, testing (with the number of cycles $10^{0}-10^{1}$ ), putting into operation, regulation of power and braking (with the number of cycles $10^{2}-10^{3}$ ), as well as technological, control, vibration, local pulsation, stationary operation modes (with the number of cycles $10^{4}-10^{12}$ ) and the emergency modes (with the number of cycles $10^{0}-10^{1}$ ). At these stages the loading parameters vary. For instance, under emergency conditions, stresses can exceed the yield stress and the ultimate strength. This causes dynamic, static or quasi-static failure. In structures under stationary conditions of operation, the rated stresses should not exceed the yield stress. They are usually lower than the limit of proportionality, ie $\sigma<<\sigma_{p r}$ (stationary vibration modes). The lower the values of cycling load, the longer the fatigue life. The mechanisms of crack formation and propagation change when fatigue enters the gigacycle and a higher range. The load at other stages may vary within a wide range of values.

Structural and technological non-homogeneity of large elements in operational conditions leads to the formation of a fatigue crack, causing its propagation and a complete failure of the element. However, the structures do not collapse immediately after the fracture process appearance inside the structural elements. Therefore, metal parts with cracks can operate for a long time. Failure caused by fatigue takes place in the following stages: (1) microcrack formation, (2) small cracks propagation, (3) propagation of large cracks and (4) ultimate failure. The first two stages are usually referred to as crack formation, while the growth of large cracks is called crack propagation. It is hardly possible to determine the transition of the developed crack to the stage of propagation. However, the period of crack formation largely determines the service life of an element, especially, under cyclic fatigue conditions. The durability (service life) of structures and elements subject to cyclic loads is the sum of the cycles number before crack formation $N_{i}$ and the number of cycles in the period of crack propagation, when it grows from the initial to critical length $N_{p}$ as shown in Fig 2a representing the relationship between the service life of mechanical elements and the interval $\Delta \sigma$ between stresses [10]. The $\Delta \sigma_{\mathrm{FL}}$ is the interval between stresses corresponding to the fatigue limit.

The design longevity of many presently operating devices has finished or is drawing to an end. Determining the remaining longevity is an important factor for assuring the safety of operating objects. The diagram of the longevity distribution of construction elements with defects is shown in Fig 2b. Excluding non-allowable operation states, the allowable crack size may be:

$$
h_{\text {adm } \max }>h_{a d m}>h_{d \text { adm }},
$$

where $h_{\text {adm max }}$ is the operational marginal size of the crack which must never be exceeded because the component may break; $h_{a d m}$ is the allowable control size of the crack determined by non-destructing control methods; $h_{d a d m}$ is the marginal size of the nonpropagating crack (the present crack does not propagate under operational loading). 


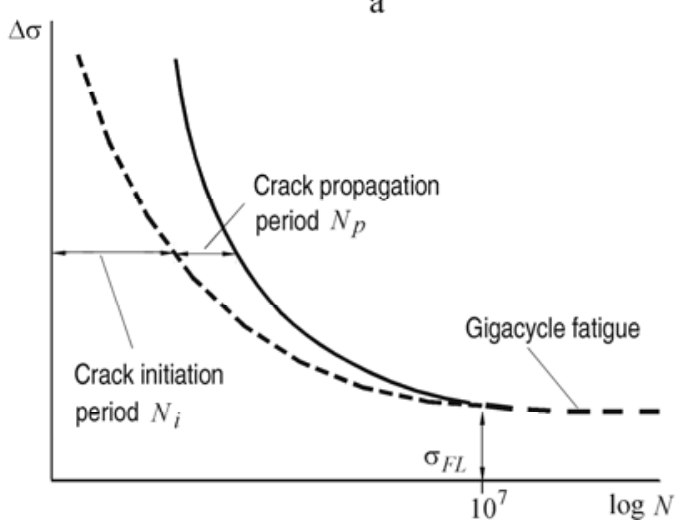

b

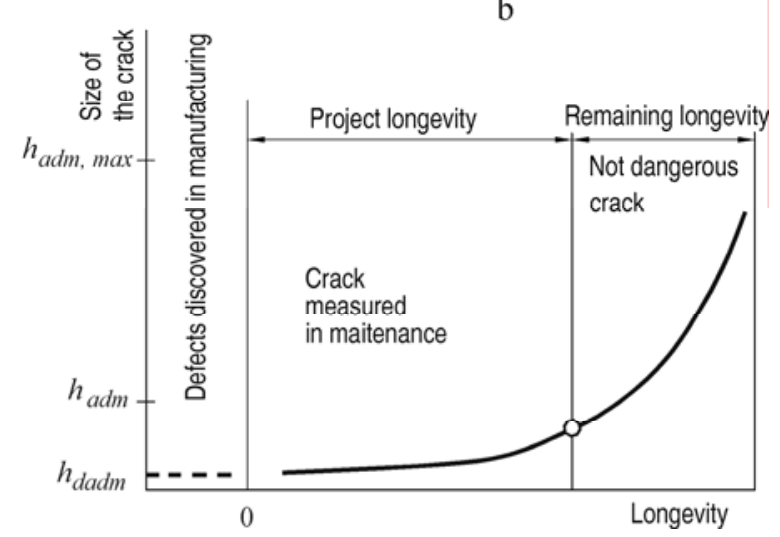

Fig 2. Durability of a structural element: a - fatigue curves corresponding to crack formation and failure, $b$ - the diagram of longevity distribution

Making use of the obtained dependencies of crack propagation it is possible to determine the duration of operation. The longevity of the structures from the initial value $h_{0}$ to the critical size $h_{c}$ (it might reach the allowable regulating value) is determined by the number cycles $N$. Structural units and elements of massive and expensive mills and crushers' equipment are paid special attention in design and operation because they determine the performance of the whole structure. Rock crushers and clinker mills are drums or cylinders which, when revolving, cause clods loaded in them to rub against each other and thus to break spontaneously. Drums are set in rotary motion by large-diameter gear drives (Fig 3).

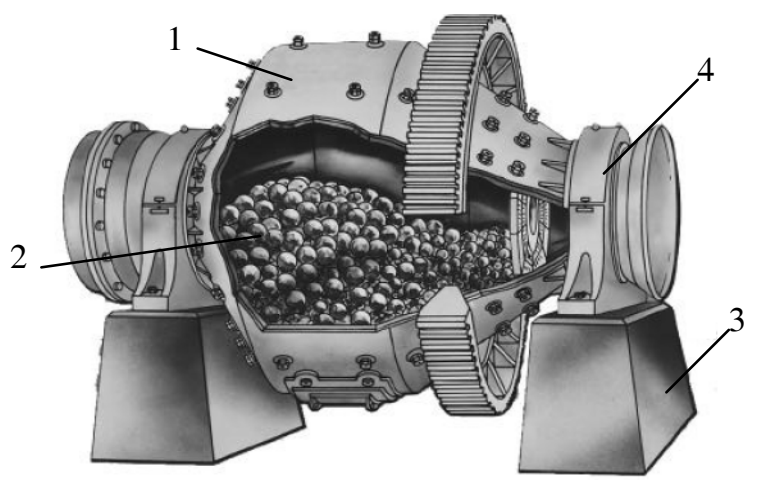

Fig 3. Scheme of crushing mill: 1 - drum, 2 - rock, 3 - supports, 4 - bearing units

The early crushing mills with autogenous grinding had quite a lot design defects causing frequent failures of the equipment. The use of the mills has revealed that their structure does not meet the requirements. Larger and more efficient and reliable crushing mills were needed. Some structural elements of the mills are now made of high-strength cast iron (eg elements of their bodies and bearing elements) and high-strength austempered ductile cast iron (ADI) (eg gear drives) to meet the requirement of more than 25 year-service life.

Casting causes some foreign material (dross) and scum to deposit on the surface of bearing units. This material of muddy structure shown in Fig 4 can cover smaller or larger surface areas, considerably decreasing wall thickness of a casting. In casting practice the thickness of dross layer can be up to $b_{1}=12 \mathrm{~mm}$. The efforts are made to eliminate the dross, however minor part may remain. Usually, this material cannot be detected by non-destructive testing. This layer can be described as the damaged area. The crack propagation characteristics in such irons were investigated [11, 12]. Thermal treatment has only a slight effect on it. Static mechanical properties of a deposit are usually worse than those of a base metal. If the above material is formed in the cross-section, it is subjected to varying load. Therefore, the strength and durability of an element depend on the layer of some foreign matter. It particularly applies to gigacycle range below the endurance limit, since inclusions of non-homogeneous material and other defects cause crack formation.

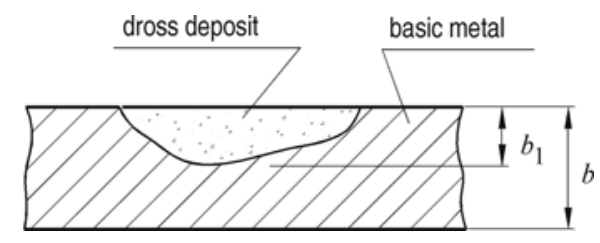

Fig 4. A casting wall with dross deposit

\section{Experiment. Analytical analysis}

The specimens were prepared according to real structures, using the same manufacturing technology. The dross layer thickness was about $10-11 \mathrm{~mm}$. The structure of the base, transitional and dross layers, were subjected to additional metallographic analyses. In the base layer, the graphite is spherical in shape. In the transitional layer, the graphite is in shape of flakes. The structure of porous layer consists of flakes, plates, inserts, different shape cavities, and non-homogeneous formations. Mechanical properties have been determined after making 3 standard cylindrical tension specimens from the base and dross layers with diameter of $10 \mathrm{~mm}$ of proving section. The mechanical properties obtained are shown in Table 1.

The specimens of a rectangular cross-section were applied to pure bending (four point) so that in external layers of proving section $(l=94 \mathrm{~mm})$ the maximum stresses rise, ie, the maximum stresses rise in the dross layer. 
Table 1. Mechanical properties of material

\begin{tabular}{l|c|c|c|c}
\hline \multicolumn{5}{c}{ Base metal } \\
\hline Proportional limit & $\sigma_{p r}, \mathrm{MPa}$ & 223 & 223 & 238 \\
\hline Yield stress & $\sigma_{02}, \mathrm{MPa}$ & 323 & 327 & 334 \\
\hline Ultimate strength & $\sigma_{u}, \mathrm{MPa}$ & 523 & 484 & 515 \\
\hline Elastic modulus & $E, \mathrm{GPa}$ & 180 & 173 & 178 \\
\hline Elongation & $\delta, \%$ & 4,6 & 3,6 & 3,3 \\
\hline Reduction of area & $\Psi, \%$ & 6,5 & 5,0 & 5,0 \\
\hline \multicolumn{5}{|c}{ Dross layer } \\
\hline Proportional limit & $\sigma_{p r}, \mathrm{MPa}$ & 150 & 142 & 157 \\
\hline Yield stress & $\sigma_{02}, \mathrm{MPa}$ & 240 & 214 & 209 \\
\hline Ultimate strength & $\sigma_{u}, \mathrm{MPa}$ & 218 & 223 & 233 \\
\hline Elastic modulus & $E, \mathrm{GPa}$ & 148 & 142 & 144 \\
\hline Elongation & $\delta, \%$ & $<1$ & $<1$ & $<1$ \\
\hline Reduction of area & $\Psi, \%$ & $<1$ & $<1$ & $<1$ \\
\hline
\end{tabular}

Before testing, the specimens were analysed by the methods of defectoscopy. Luminescence magnetic method was applied to determine small defects. During the cyclic loading the test machines were periodically stopped to measure the propagation of cracks on non-machined surfaces of dross layer. According to the loading program up to $10^{8}$ cycles, the maximum stress was $\sigma_{\text {max }}=42,8 \mathrm{MPa}$ and the minimum $\sigma_{\min }=-26,2 \mathrm{MPa}$ with the range of stress $\Delta \sigma=69 \mathrm{MPa}$. The stresses were calculated assuming that the specimens were continuous and homogeneous. Up to $10^{8}$ cycles the defects - cracks have increased insignificantly.

After $10^{8}+2 \cdot 10^{6}$ cycles the side walls of the specimens were cut off by $0,5 \div 1,0 \mathrm{~mm}$ every $10^{6}$ cycles to specify the behaviour of the cracks deeper in the metal. The cutting scheme is in Fig 5. It helped better determine the cracks behaviour at a particular cycle number and loading. The cutting enabled to observe that some cracks had decreased and the others - increased. During the experiments the colour imprint and the optical methods were also adopted to measure the crack size. The cracks depths have been revised additionally according to front shape. For stress intensity factor $K$ calculations, the assumption that crack front is parallel to specimens surfaces was used. Retaining the stress ratio $r=-0,62$, the stress range was changed: $\Delta \sigma=69 \mathrm{MPa}, N=1 \cdot 10^{8}$; $\Delta \sigma=90 \mathrm{MPa}, N=2 \cdot 10^{7} ; \Delta \sigma=110 \mathrm{MPa}, N=2 \cdot 10^{7} ; \Delta \sigma=$ $140 \mathrm{MPa}, N=2 \cdot 10^{7} ; \Delta \sigma=150 \mathrm{MPa}, N=2 \cdot 10^{7} ; \Delta \sigma=160$ $\mathrm{MPa}, N=2 \cdot 10^{7} ; \Delta \sigma=170 \mathrm{MPa}, N=2 \cdot 10^{7} ; \Delta \sigma=180$ $\mathrm{MPa}, N=6 \cdot 10^{7}$ (specimen 1) and $\Delta \sigma=70 \mathrm{MPa}$, $N=1 \cdot 10^{8} ; \Delta \sigma=150 \mathrm{MPa}, N=2 \cdot 10^{7} ; \Delta \sigma=160 \mathrm{MPa}$, $N=2 \cdot 10^{7} ; \Delta \sigma=170 \mathrm{MPa}, N=4 \cdot 10^{7} ; \Delta \sigma=180 \mathrm{MPa}$, $N=1 \cdot 10^{7} ; \Delta \sigma=200 \mathrm{MPa}, N=1 \cdot 10^{7} ; \Delta \sigma=220 \mathrm{MPa}$, $N=1 \cdot 10^{7} ; \Delta \sigma=240 \mathrm{MPa}, N=1 \cdot 10^{7} ; \Delta \sigma=260 \mathrm{MPa}$, $N=1 \cdot 10^{7} ; \Delta \sigma=280 \mathrm{MPa}, N=2 \cdot 10^{7}$ (specimen 2).

The testing programme in the gigacycle loading range was coordinated to determine the crack appearance in the defective places and to observe crack propagation in the dross and main layers.

In Fig 6 the extension of longitudinal cracks on the surface of the specimens 1 and 2, depending on the number of loading cycles, is shown. The breaks in the curve are caused by the variation of the programmed loading. The length of the above crack is the total length of small cracks on the trajectory of the main crack.

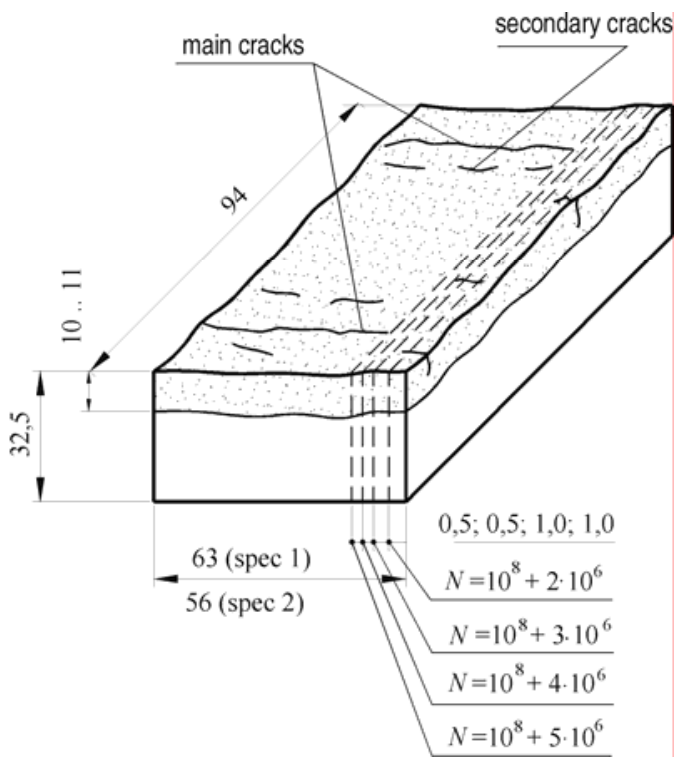

Fig 5. The cutting scheme and the proving segment of specimen

The main crack causing a complete failure of a specimen or an element is formed due to a number of factors. Non-localised fatigue crack-like defects on the specimen surface may occur in a large area with local plastic deformation zones. A great number of unevenly spread crack-like defects and inclusions of nonhomogeneous material causing crack formation are found in the surface structure of cast iron. Small cracks are extending and propagating deeper in the cross-section of a specimen under the cyclic loading.

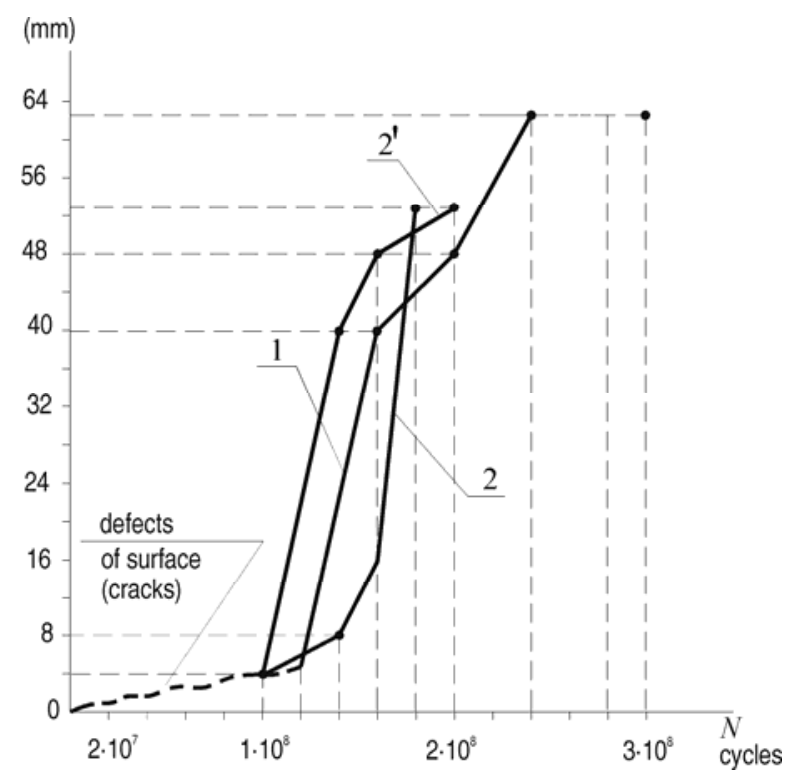

Fig 6. Dependence of crack length on the cycle number: 1 - specimen number $1 ; 2$ - specimen number 2 by cyclical break; 2' - specimen number 2 by statical break

It is interesting to observe that two main cracks have been formed in the second specimen as a result of merging smaller cracks extending on different planes of the specimen subjected to various numbers of loading 
cycles. Under an increasing cyclic load, they are extending in length and depth. For $K$ determining the generalised crack depth was used.

To define crack propagation rates, the stress intensity factor was determined.

The assumption was made that crack propagation front is parallel to the specimen surface. Then the stress intensity factor $K_{1}$ for rectangular cross-section specimen in pure bending can be calculated according to the formula:

$$
K_{I}=\sigma \sqrt{\pi a} f(\alpha)
$$

where $\sigma-$ maximum tensile stress in crack zone; $a-$ initial crack length; $f(\alpha)$ - geometry function:

$$
f(\alpha)=1,122-1,40 \alpha+7,33 \alpha^{2}-13,08 \alpha^{3}+14,0 \alpha^{4},
$$

where $\alpha-$ is the ratio of the crack length $a$ to the specimens width $W$.

Crack propagation rate versus the maximum stress intensity factor (according to programmed loading) in two layer plates are shown in Fig 7.

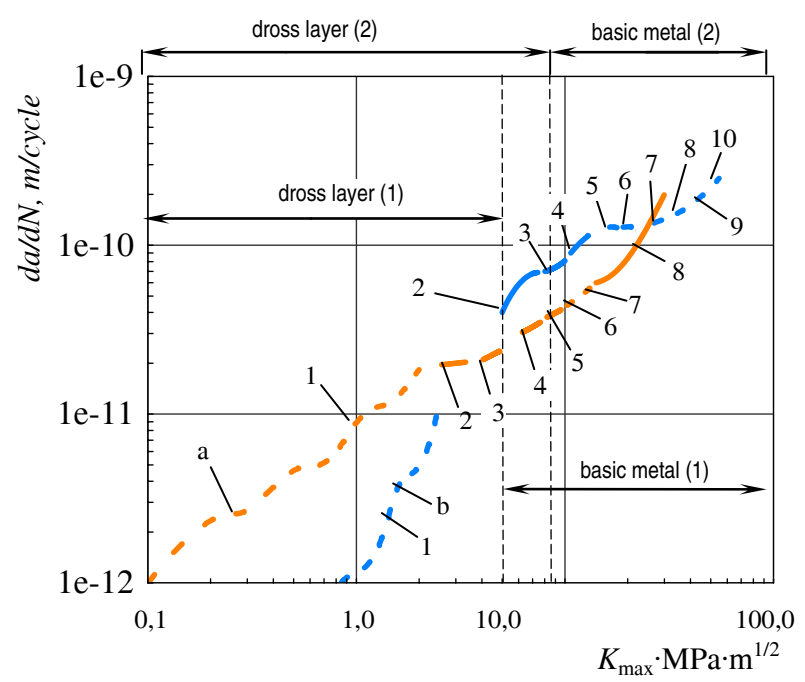

Fig 7. Crack growth rate in plates versus the maximum stress intensity factor: $\mathrm{a}-$ specimen $1, \mathrm{~b}-$ specimen 2 (1-10 - numbers of program loading cases)

To determine the stress intensity range threshold $\Delta K_{t h}$, the CT specimens were made of the basic metal and dross layer (their width is $\mathrm{W}=42 \mathrm{~mm}$ and thickness $\mathrm{B}=10 \mathrm{~mm}$ ). The dependences of crack growth rate versus the stress intensity factor range were determined (Fig 8) by testing requirements and the specified calculation technique (according to ASTM E 647-00). In the CT specimen made of basic metal, the crack plane was perpendicular to bending normal stresses.

The threshold of dross layer is $\Delta K_{t h}=7,7 \mathrm{MPa} \cdot \sqrt{\mathrm{m}}$. The threshold of base metal is $\Delta K_{t h}=9,3 \mathrm{MPa} \cdot \sqrt{\mathrm{m}}$.

In the specimen made of dross layer, crack formation and propagation depend on many factors.

At the initial stage (crack depth $2-3 \mathrm{~mm}$ ) crack is formed in the area, which is under the influence of the CT specimen notch (concentrator) and is almost perpen- dicular to normal stresses. The heterogeneity and anisotropy of separate layers of material have a great influence on further crack propagation. Cavities, heterogeneous formations and inserts change the stressstrain state at crack tip. The integral influences of structure on the separate segments determine the crack propagation, thus its trajectory passes through slip planes and cavities in various directions. On the sides of CT specimen, the crack changes not only its direction, but split into separate fronts.

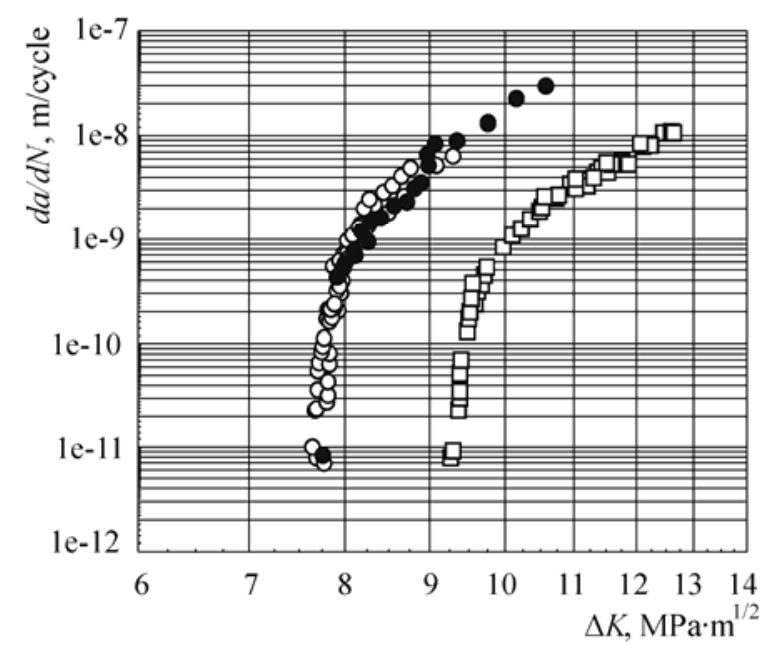

Fig 8. Crack growth rate versus the stress intensity factor range $(\circ, \bullet-$ dross layer, $\square-$ basic metal $)$

The zigzag crack path was determined by the microstructure. Therefore the obtained dross layer's threshold $\Delta K_{t h}$ is conditional, taking into account the assumption that a crack is perpendicular to normal bending stresses. It should be noted that the obtained data are similar to two specimens. The views of fractures of semi-natural and compact tension specimens are shown in Figs 9, 10.

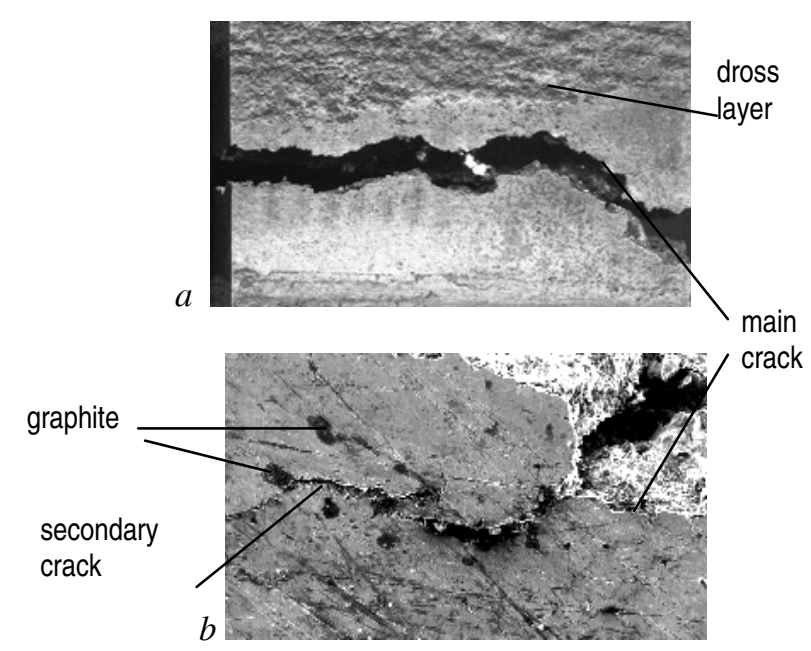

Fig 9. Cracks of semi-natural specimens: a - surface of dross; $b$ - surface/secondary crack 

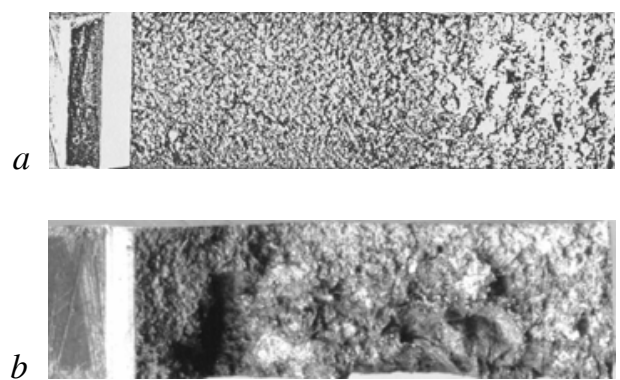

Fig 10. Fracture surfaces of CT specimens: a - fracture surface of CT specimen of basic metal; b - fracture surface of CT specimen of dross layer

\section{Discussion}

The threshold of stress intensity factor range $\Delta K_{t h}$ also depends on stress ratio, temperature, environment effect, overloading, non-homogeneity and other factors. The investigations [1, 2] disclose the increase of threshold $\Delta K_{t h}$ and fatigue crack growth rate under the change of stress ratio from 0 to 0,9 , stress concentration and surface conditions [13]. For practical calculations of $\Delta K_{t h}$, by assessing the stress ratio $r$, can be used the expression [1]:

$$
\Delta K_{t h}=\Delta K_{t h 0}(1-r)^{\gamma},
$$

here $\Delta K_{t h 0}$ is the limit range of stress intensity factor, when $r=0 ; \gamma$ is the coefficient dependent on the material and fluctuates from 0,5 up to 1 . Formula (4) shows a good agreement for steel, when $0<r<0,6$.

In the fracture mechanics the general expression of stress intensity factor is

$$
K_{1}=Y \cdot \sigma \sqrt{a+a_{0}}
$$

here $Y$ is geometric factor; $\sigma$ is stress, $a$ is crack size, $a_{0}$ is structural defect size.

When $a=0, \sigma=\sigma_{R}$ (durability limit), $K_{1}=\Delta K_{t h}$, we shall have the threshold stress intensity range

$$
\Delta K_{t h}=Y \cdot \sigma_{R} \sqrt{a_{0}} .
$$

If there is a crack of the length $2 l$ on the surface of a detail, the crack development will be stopped, when the limit stress interval correspondent with $\Delta K_{t h}$ does not exceed $\Delta \sigma_{t h}$ calculated by formula

$$
\Delta \sigma_{t h}=\frac{\Delta K_{t h}}{Y \sqrt{2 l}} .
$$

The obtained results of experimental and analytical investigation of semi-natural and CT specimens may be applied to design calculations of real structural elements. The short crack behaviour was not analysed in this paper.

\section{Conclusions}

1. The mechanical characteristics, hardness and strength of the structure differ significantly in the base and dross layers.

In the base layer, the graphite is spherical in shape. The structure of dross layer consists of flakes, plates, inserts, different shape cavities, and inhomogeneous formations.
2. It has been found that the ultimate strength of basic metal $\left(\sigma_{u}=507 \mathrm{MPa}\right)$ is 2,2 times greater than that of the dross layer $\left(\sigma_{u}=225 \mathrm{MPa}\right)$. Basic metal threshold $\left(\Delta K_{t h}=9,3 \mathrm{MPa} \cdot \sqrt{m}\right)$ is 1,2 times greater than that of the porous layer $\left(\Delta K_{t h}=7,7 \mathrm{MPa} \cdot \sqrt{m}\right)$.

3. Testing the CT specimens taken from the dross layer has shown that there simultaneously exist opening and shear crack surface displacement modes.

4. The experimental and analytical investigations show that the computation of constructions elements can be validated by stress intensity factor of the damaged layer.

\section{References}

1. Anderson, T. L. Fracture mechanics. USA, Boston, CRC Press, 1991. 793 p.

2. Panasiuk, V. V.; Savruk, M. P.; Jarema, S. J.; Makhutov, O. N.; Romaniv, O. N.; Andreikiv, A. E.; et al. Fracture mechanics and strength of materials (Механика разрушения и прочность материалов). Kiev: Naukova dumka, 1988-1990. Vol 1, 488 p.; Vol 2, 620 p.; Vol 3, 436 p.; Vol 4, 680 p. (in Russian).

3. Kenneth G. Budinski; Michael K. Budinski. Engineering materials. Properties and selection. Pearson Prentice Hall, 2005. $885 \mathrm{p}$.

4. Park, J.S.; Kim, S. J.; Kim, K. H.; Park, S. H.; Lee, C. S. A microstructural model for predicting high-cycle fatigue life of steels. Intern Journal of Fatigue, Vol 27, Issue 9, 2005, p. $1115-1123$.

5. Sugeta, A.; Yematsu, Y.; Hashimoto, A.; Jono, M. Atomic force microscopy of fatigue crack growth behaviour in the low K region. Intern Journal of Fatigue, Vol 26, Issue 11, 2004, p. 1159-1168.

6. Leonavičius, M.; Šukšta, M. Shakedown of bolts with a one-sided propagating crack. Journal of Civil Engineering and Management, Vol 8, No 2, 2002, p. 104-107.

7. Bathias C. Designing components against gigacycle fatigue. In: Proc of the Int Conf on Fatigue in the Very High-Cycle Regime. Vienna, Austria (eds S.Stanzl-Tschegg and H. Mayer) 2001, p. 97-109.

8. McDowell, D. L. Basic Issues in the Mechanics of High Cycle Metal Fatigue. Intern Journal of Fracture, Vol 80, No 2, 1996, p. 103-145.

9. Makhutov, N. A. Fatigue of metals in a wide range of cyclic loading. Industrial laboratory (Заводская лаборатория), Vol 70, No 4, 2004, p. 37-41 (in Russian).

10. Glodež, S.; Šraml, M.; Kramberger, J. A computational model for determination of service life of gears. Intern Journal of Fatigue, Vol 24, Issue 10, 2002, p. 1013-1020.

11. Leonavičius, M.; Petraitis, G.; Krenevičius, A.; Šukšta, M; Stupak, S. Investigation of high-cycle fatigue of cast iron with porous layer near threshold $\Delta K_{t h}$. Kovove mater., 43, 2005, p. 348-357.

12. Bobyliov, K.; Leonavičius, M.; Šukšta, M; Krenevičius, A.; Stupak, S. Resistance to crack propagation of alloyed structural and cast steels. Mechanics (Mechanika), No 4(54), 2005, p. 12-17.

13. Stoychev, S.; Kujawski, D. Analysis of crack propagation using $\Delta K$ and $K_{\max }$. Intern Journal of Fatigue, Vol 27, Issue 12, 2005 p. 1425-1431. 


\section{MEDŽIAGŲ, SKIRTŲ MALŪNŲ IR UOLIENŲ SMULKINTUVŲ IRENGINIAMS, ATSPARUMAS GIGACIKLEI APKROVAI}

\section{K. Leonavičius, G. Petraitis, M. Šukšta, V. Svalbonas}

\section{Santrauka}

Uolienų smulkintuvų ir cemento klinkerio malūnų atraminių mazgų gamybai naudojamas stiprusis ketus. Didelių matmenų detalèse liejimo proceso metu lieka nuodegu ir neaiškių pagrindinio metalo darinių. Jų blogesni mechaninių savybių rodikliai ir geba priešintis plyšio atsiradimui bei plitimui. Straipsnyje pateikiami pusiau natūrinių stačiakampio skerspjūvio bandinių iš ketaus su $10-11 \mathrm{~mm}$ storio nuodegų sluoksniu eksperimentiniai ciklinio lenkimo tyrimo rezultatai. Prieš eksperimentą defektoskopijos metodu buvo nustatyti technologiniai defektai. Ciklinio deformavimo asimetrijos koeficientas $r=-0,62$, itempių intervalas kito nuo $70 \mathrm{iki} 280 \mathrm{MPa}$. Ciklų plyšiai iki $1 \cdot 10^{8}$ didejo nežymiai. Toliau varginant ir didinant itempių intervalą, plyšio augimas buvo kontroliuojamas. Pirmasis bandinys suiro po $3 \cdot 10^{8}$, antrasis - po $2 \cdot 10^{8}$ ciklų. Eksperimentiškai nustatyta plyšio plitimo rodiklių priklausomybė nuo ciklų skaičiaus ir įtempių intensyvumo koeficiento kitimo intervalo. Plyšio plitimą stabdo tarpinis sluoksnis, pereinant nuo nuodegų sluoksnio į pagrindinį metalą.

Reikšminiai žodžiai: uolienų trupintuvas, nuovargis, plyšio plitimas, įtempių intensyvumo slenkstis.

Mindaugas Kazimieras LEONAVIČIUS. Prof Dr Habil at the Dept of Strength of Materials, Vilnius Gediminas Technical University, Lithuania. Author of more than 100 scientific articles. Research interests: fatigue, fracture mechanics and shakedown.

Gediminas PETRAITIS. PhD student at the Dept of Strength of Materials, Vilnius Gediminas Technical University, Lithuania. Research interests: fatigue, fracture mechanics.

Marijonas ŠUKŠTA. Doctor, Assoc Professor at the Dept of Strength of Materials, Vilnius Gediminas Technical University, Lithuania. Research interests: analysis of elasto-plastic strain hardening structures and shakedown.

Vytas SVALBONAS. Director, Engineering Technologies Metso Minerals, USA. Research interests: fatigue, fracture mechanics, longevity of structures. 